\title{
People's Voting Behavior In Local Election: A Study On Annadanagar Union Parishad, Pirgachha , Rangpur.
}

\author{
${ }^{1}$ (Md. Kazi Rezuan Hossain, ${ }^{2}$ (Most. Munmun Aktar, ${ }^{3}$ (Md. Shariful Islam, \\ ${ }^{1}$ (Lecturer, Department Of Political Science, Begum Rokeya University, Rangpur, Bangladesh, \\ ${ }^{2}$ (MSS Research Student, Department Of Political Science, Begum Rokeya University, Rangpur, Bangladesh \\ ${ }_{3}^{3}$ (Assistant Professor, Department Of Political Science,Begum Rokeya University, Rangpur, Bangladesh,
}

\begin{abstract}
Voting is the main form of political participation in democratic societies and the study of voting behavior is a highly specialized sub-field in political and social science. The study was concerned with the reasons why people vote the way they do. The main objectives of the present study were to find out the factors why some citizens vote while others do not, comparing the voting behavior of the casting and non-casting voters and the influences of socio-economic and political determinants of voting behavior of the local people. That study has diagnosises the inner catalyst behind the changing trend of voting behavior in democratic form of local self-government in local area in Bangladesh. The changing pattern of voting behavior influenced by both political and non-political variables .Socio-economic factors also responsible for changing mode of voting behavior in rural election and also in case of national election, it also varies to casting voters and non-casting voters. Voting behavior has many determinants such as demographic factors like age, education, gender, and occupation etc. and. Socio- politico and economic factors such as, political ideology, party affiliation, candidates 'qualification, family affiliation etc. which had strong effect on voting decisions, this study specifically explored the relationship of voting behavior with the socio- politico and economic determinants. As survey area I have selected Annadanagar Union Pirgachcha,Rangpur which is a typical Union in Bangladesh which represents most of the Union of Bangladesh. To know about the voting behavior of the local people towards local elections a sample of 200 respondents were selected randomly from Annadanagar Union through multistage sampling technique. Mainly this study is qualitative but to make the study more explicit the quantitative method also used. And the interview was taken through open- ended and close-ended question. The findings of study have consistency with the set objectives.
\end{abstract}

Keywords: Voting, Local-election, Voting Behavior, Casting Voter, Non-Casting Voter

\section{INTRODUCTION}

Voting is one of the most fundamental aspects of civic engagement. Many political scientists link voting with the vibrancy of the democratic process and argue that declining voting rates may be symptomatic of a "democratic deficit". Because political participation can also influence public policy, others are concerned that lower participation could result in policies that are not necessarily representative of key constituencies, like those who tend to vote less frequently. As a result, the voter turnout rate is used as one indicator of civic engagement. Voting is also the key mechanism of consensus building in a democratic society (Lipset: 1960). Voting behavior is a set of personal electoral activities, including participation in electoral campaigns, turnout at the polls, and choosing whom to vote outlines the comprehensiveness of the study of voting behavior(Bratton: 2013). In that light, attempts have been made to understand national voting behavior and various factors that influence voters in determining voter's choice. Works have been done on the question of holding free and fair election system, factors that influence voter's choices such as voter's ethnic religious identity, voting simulation models, and voting pattern and trends. There are three kinds of voters; such as i) Regular Voter, who get involved in election-related activities and cast their vote regularly; ii) Intermittent Voters, who get involved in election-related activities and cast their vote but not as regularly as the regular voters do; and iii) Non-Casting Voters; who don't get involved in election-related activities and don't cast their vote. In local elections of Bangladesh, generally speaking, roughly more than $80 \%$ of the voters cast their votes and the rest tend not to cast their votes. This number (80\%) is quite in tune with a working democracy. Nonetheless an enigma prevails and that is: Although voter turnout rate is good enough compared to national election why is it that some voters cast their votes while a section of the voters no matter how small or large that size might be. What are the factors that determine one large section of the voters to vote and what are the factors that discourage other section of the voters not to get engaged in electoral activities and turnout to vote? 
This study is a modest attempt to understand the factors that motivate some voters to get engaged in voting related activities and the factors that dissuade or discourage others-the not engaged voters-to engage themselves in voting related activities including voting in local elections.

\section{LITERATURE REVIEW}

Kamal Siddiqui (2000),discussed in his book on the evolution of local self- government, economic structure, administrative structure, identification of the problem and possible solution.Rounaq Jahan (1980), his book dealt with characteristics of Bangladesh`s election process political tradition and the impact of political parties on voting behavior of the people in national and local election. The author also discussed about the social, economic and hereditary influence and power of the personnel of the political party. But the author became failed to illuminate the causes of the voting and non-voting of the people in the local election. Nizam Ahamed (2000), focused on the local government in Bangladesh and widely emphasized on the role that' should be played by the political leaders, activists, and administrative officers in the local government system in Bangladesh. In his book, he has dealt with the relationship between chairman and bureaucrats in conduct the activities of local government. But the author didn't take into consider the importance of voting behavior of the people in the local area which actually has great effect on the local government system.M Abdul Wahab (1986),Focuses on the voting behavior of the local people such as how the people enter into politics and by whom etc. these issues are the highlights of this book. This book illustrated how the local people get involved in the politics by rich peasants, educated family, and village-lords.Shamsul Huda Harun (1986), in his book he discussed the first parliamentary election and Union Parishad election in Bangladesh which was held in 1973. Here the authors tried to examine the voting behavior of the people, the process of getting support of the political parties, the influence of the political leader on the voter, monopoly tendency of the political leader in the decision making process. Without these, party manifesto, election campaigning, meeting, seminar of the supporter, etc also get priority in this book.

\section{OBJECTIVES OF THE STUDY}

The overall objective of the study is to examine the voting behavior of the local people in local elections in Bangladesh. Specifically the voting behavior of the people of Annadanagar Union, Pirgacha, Rangpur, has been examined in this research.

The specific objectives of the research are:-

i. To investigate the determinants that contribute to the voters decision either to cast vote or not to cast votes.

ii. To compare the voting behavior of voters who cast their vote and non-casting voters.

iii. To find out and analyze the influence of socio-demographic determinants such as ethnicity, gender, religion education age etc. and politico- psychological factors such as perception, security situation, local factors, party affiliation, ideological affiliation of candidates and voters, etc. in determining voters choices such as either to voter or whom to vote and whom not to.

\section{CONCEPTUAL FRAMEWORK}

Election is the process of electing public representatives, receiving and giving public opinion through casting votes in ballot. Election is a prerequisite of democracy which plays a significant role in institutionalizing of democracy. Elections considers as the major political events of the political system which shape the political behavior.Voting behavior is a form of political behavior. Understanding voters behavior can explain how and why decisions were made either by public decision-makers, which has been a central concern for political scientists (Goldman: 1966). Through the voting behavior we can know the will of the people and the way they want to have it. The study of voting behavior related to learn about the nature of political system and provides information about the process of political system. Voting is the main form of political participation in a democratic society and its study in political science is highly specialized in the sub-fields (Cohen: 2003). The registered citizens are only eligible to cast their vote. Voting defined by Universal Declaration of Human Right as" Voting is the fundamental right of all citizens over the age of eighteen". Voting is the expression of a person's preference for a candidate, or a group of candidates as well as the person's preference of one political system rather than other (Blais et al: 2004).The analysis of voting pattern focused the determinants such as, why people vote and how they make the decisions. Sociologists look at the socio-economic determinants such as support of political parties, occasions, ethnicity and gender, correlation between the classes, age and vote (Lednum: 2006). "While, political scientists focused on the influence of voting behavior of political factors such as political programs, electoral campaign, issues and popularity of leaders of the political parties contesting elections," (Jost : 2006)According to the local government act local election refers to the city corporation, Upazilla election, Paurasava, Union Parishad and village Parishad election. Before, the political party couldn`t participate in the election through candidate selection and election campaigning but according to the new law 
the political party can participate in the local election through candidate selection and others. As a result the new system of Union Parishad election has great impact on the voting behavior of the local people.

\section{1 :Legal Framework of Local Election}

Article 59 and 60 of third chapter of the Bangladesh constitution stated about the local government system. According to the constitution, the responsibility to conduct the local and national election is in the hand of election commission and the parliament has the right to make any law which is necessary for the local election.

\section{1(a): Local Government Act 1973 (Union Parishad)}

In 1971, on 16 December Bangladesh had gained a place in the world map as an independent and sovereign state. And after in the post war period the great challenge for Bangladesh was to make a constitution as soon as possible. In November, 1972 a full-fledge constitution was formulated by the constituent assembly, which came into force on 16 December, 1972. In the article 59 and 60 stated about the organization of local Government. But the responsibility of law making is in the hand of parliament. In this perspective the government made 1973 law at that time. This new law creates a new post of vice-chairman in Union Parishad.

\section{1(b): Local Government Act 1976 (Union Parishad)}

In 1976 the government of that time proclaimed an ordinance of local government. This ordinance organized the local government system and disowned the post of vice-chairman. Further as the act of 1973 this act kept the local election nonpolitical. The 1977 union parishad and pourasava election was held under this law.

\section{1(c): Local Government Act 1983}

H.M. Ershad proclaimed the ordinance of local government on 9 August 1983. Through this ordinance a great change has been brought of the 1973 and 1976 law of local government. This is the tenure of chairmen has been decreased from 5 years to 3 years. Non-party system is also remained here in this ordinance.

\section{1(d):) Local Government Act 2009}

On October 15, 2009 Local Election (Union Parishad) Act 2009 was proclaimed. According to this Act Union Parishad composed with 13 members and they elected by the direct vote of the local people, among the 13 members, one chairmen, three female members and nine male members. And the all local elections are held under the election Commission. According to this Act no candidate can election not more than one post.

\section{1(e): Union Parishad at Present}

At present in Bangladesh, the Union Parishad is constituted under the legal basis of the constitution of Bangladesh. In section 9, 10, 11, 59 and 60 of the constitution the formation, responsibility and functions of the local government institutions has been described. Based on those sections the Union Parishad operates according to The Local Government (Union Parishad) Ordinance, 1983 and its elections are held according to the Union Parishad(Election) Rules, 1983.The Union Parishad is constituted of 1 Chairman and 12 members. Among the 12 members, 3 seats are reserved for women. Each Union is divided into 9 wards and each ward has 1 member elected directly by people's votes. Every 3 ward's voters will elect 1 women member for the reserved seats. But any women voter of the Union can elect a member for any of the 9 wards besides the reserved 3 seats. At present only Union Parishad is an elected local government body.

\section{1(f): Structure of the Union Parishad}

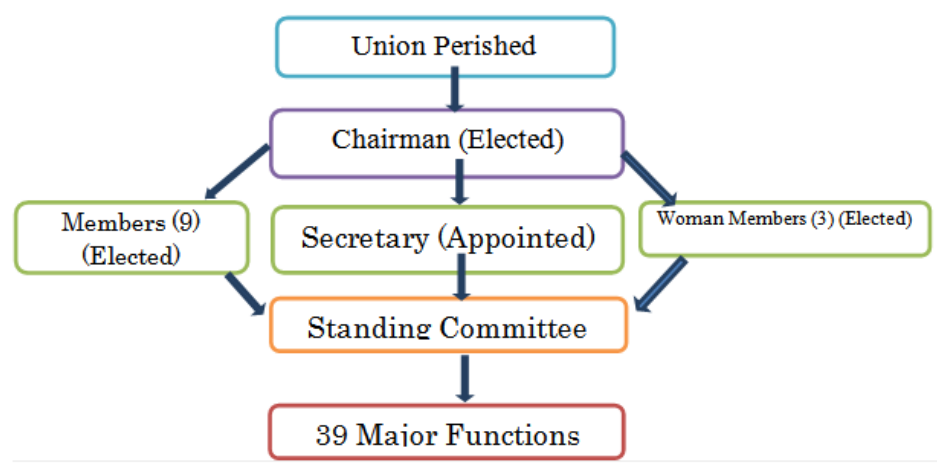




\section{METHODOLOGY OF THE STUDY}

\section{1 : Description of the Research Area}

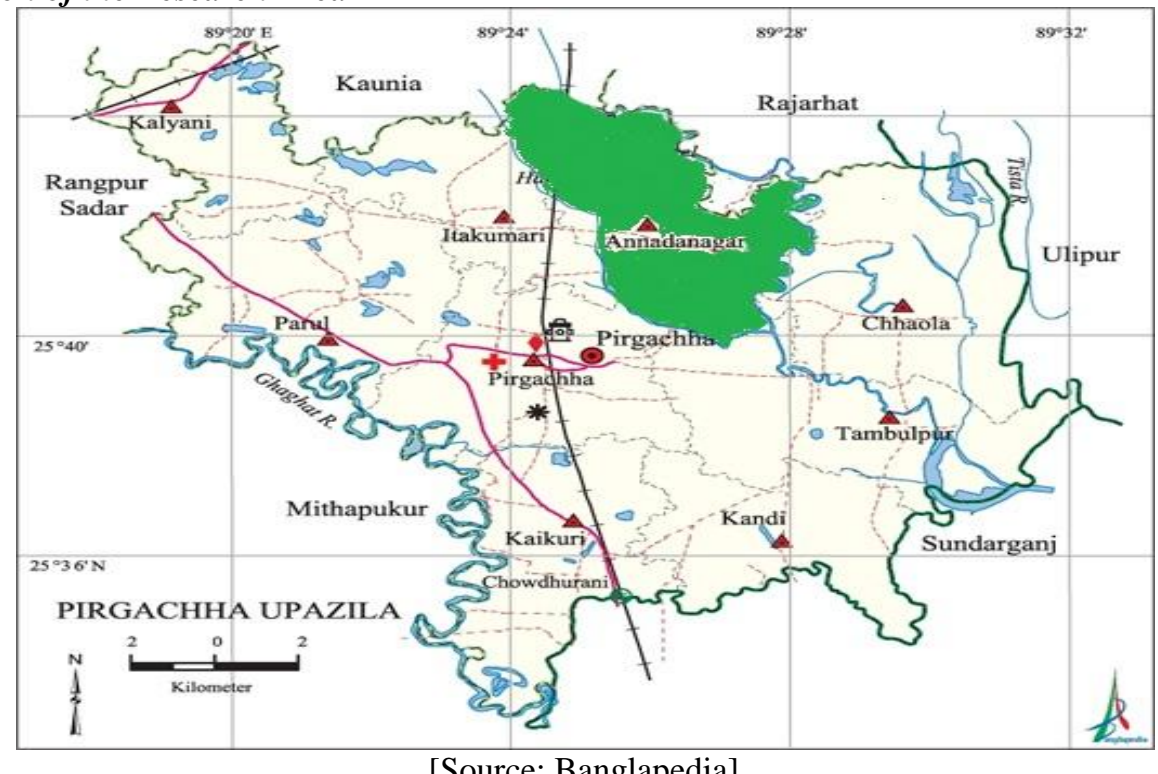

[Source: Banglapedia]

The present study has selected a Union which is called Annadanagar. Annadanagar Union is under Pirgachha Thana in Rangpur District. It is a typical Union of Bangladesh from the considerations of location, population, economy, infrastructure, socio-demographic characteristics of the population, and so on. Geophysically, the Union is located in a low land area. Total area of Annadanagar is about 40.10 square kilometer which indicates that the union is big in size. The union is fragmented into 22 villages. The total population of the union is about 39000 which include both male and female. Total percentage of the population is 50.8 and 49.2 respectively. Most of the inhabitants are Muslim and a few Hindus. The mode of production of Annadanagar is predominantly agricultural. Most of the people are employed in agriculture. Except a few ones there are twelve government primary schools, seven secondary school, two colleges and three Madrasha under the Annadanagar Union. Two or three moqtabs (religious learning institution) are run under the fabric of each mosque under each village of this Union. Radio and television are frequently used in many families of the Union and satellite connection of television has been found in the Union.

\section{2: Sources of the Data}

In this study data and information are mainly collected from the primary source namely,through field survey in the Annadanagar Union, Pirgacha, Rangpur. Where primary data could not be obtained, secondary data such as books, journals, newspaper reports, articles (published and unpublished) had been studied with care to develop possible explanation. Primary data are collected on the basis of field survey from Annadanagar Union, Pirgachha, Rangpur through a set of standard questionnaire. Questionnaire was both open ended and close ended and was pre-tested in the field before finalization. From the respondents observation method was also used in this research.

\section{3: Data Collection Process}

The present study is exploratory in nature. Both quantitative and qualitative approach was applied to collect the relevant data based study in accordance with aim and objectives. All quantitative data were collected in the mode of face-to-face interviews. Each interview lasted for about 25-30 minutes

\section{4: Sampling: Study Design and Sample Design}

The data collected by using multi stage survey design. The number of households/sample will vary depending on targeted groups. This study will be based mainly on descriptive study since the study will focus on an accurate event trying to answer what, where, how, who and when questions through the use of different sources, information and already existing theories. With our set objectives, and to understand our chosen subject, we laid emphasis on the qualitative research method as well as some level of quantitative approach. The primary research instrument was structured questionnaire administered to 200 numbers of respondent's in-depth interviews with different respondents. Respondents were selected randomly from Annadanagar Union Parishad, Pirgachcha, Rangpur. 


\section{4: Survey Instrument and Survey}

I, personally, with the help of a team which composed with five educated male and five educated female and some local guides have been collected data. Before going to field survey, I trained them carefully about this matter.

\section{6: Data Representation and Explanation}

The data collected from the research area have been represented through different tables and images for analysis. Beside that the information collected has been represented through computer programs like Statistical Program for Social Science (SPSS), MS-Excel, MS-Word. Finally analyzed have been presented in form of tables and graphs, charts along with interpretation and analysis of the numbers therein.

\section{RESULT ANALYSIS}

\section{1: Number of Voters and Non-Casting Voters}

The number of voters and non-casting voters among the total 200 respondents are shown in the following chart on the basis of field survey.

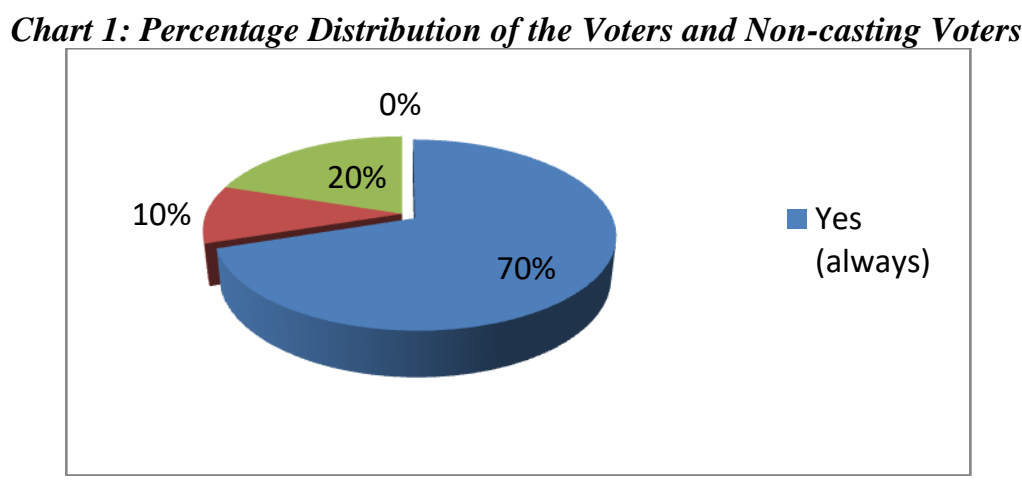

Chart 1- demonstrates that among 200 respondents, $70 \%$ voter cast their vote in the local election always, $10 \%$ cast their vote sometimes, $20 \%$ don't cast their vote and the percentage of no response is $0 \%$ as per table no.5.1. From this chart it become proved that the people of Annadanagar Union are enough conscious about casting their vote in the Union Parishad election because total $80 \%$ cast their votes (always+ sometimes).

\section{2: Causes of Voting}

After interviewing of the voters of the Annadanagar Union I find out some reasons of their participation in voting. Some variables that definitely influence and turning out the number of voters to participate election. How many voters vote for which causes the following table presents that percentage.

Table 3: Percentage Distribution of Various Causes

\begin{tabular}{|l|l|l|}
\hline \multicolumn{1}{|c|}{ Causes } & Frequency & Percentage \\
\hline Political ideology & 40 & $25 \%$ \\
\hline Interested in politics & 30 & $18.75 \%$ \\
\hline Candidates qualification & 35 & $21.88 \%$ \\
\hline Candidate from my locality & 20 & $12.5 \%$ \\
\hline Candidate from my religion & 15 & $9.4 \%$ \\
\hline Citizen's obligation & 20 & $12.5 \%$ \\
\hline & Total- 160 & Total-100\% \\
\hline
\end{tabular}

[Source: Field survey]

The above table illustrates that; there are some specific causes behind the thinking of the people whose casting their vote (always/ sometimes). Among 160 (80\% of total respondents) casting voter, $25 \%$ cast their vote for the cause of political ideology, $18.75 \%$ for interested in politics, $21.88 \%$ for candidates qualification, $12.55 \%$ for locality, $9,4 \%$ for religious factor, and $12.5 \%$ for the cause of citizen's obligation. Maximum numbers of the voters of Annadanagar Union said that they votes for political ideology and candidate's qualification. 


\section{3: Reasons for Not-Casting Vote}

The non-casting voters of 200 respondents remarked some important reasons of their not voting in the election. The results of the question why you don't vote in the election are given in bellow on the basis of field survey.

Table 4: Respondent's Opinion on Various Causes of Not-Casting Vote

\begin{tabular}{|l|l|l|}
\hline Causes & Frequency & Percentage \\
\hline Not interested in politics & 5 & $12.5 \%$ \\
\hline Not hope to benefited & 10 & $25 \%$ \\
\hline None of the candidate is my Liking & 3 & $7.5 \%$ \\
\hline Electoral system is not free and fair & 15 & $37.5 \%$ \\
\hline No candidate from my religion & 4 & $10 \%$ \\
\hline No candidate from my area & 3 & $7.5 \%$ \\
\hline & Total-40 & Total-100\% \\
\hline
\end{tabular}

[Source: Field survey]

The table presents the causes of non- casting vote which bear the information about the non-casting voter of Annadanaagar Union. Among 40 non-casting voter (20\% of total respondents) $12.5 \%$ don't cast their vote for not interested in politics, $25 \%$ for note hope to benefitted, $7.5 \%$ for don't liking of candidate $37.5 \%$ for default electoral system, $10 \%$ for religious factor, $\& .5 \%$ for locality. Majority percent voters ceased themselves from participate in vote for the default electoral system so it is a great problem in the local election system.

\section{4: Relationship between Age and Voting Behavior}

The changing pattern of voting behavior on the basis of age is in the following table

Table 5: Percentage Distribution of Age and Voting Behavior

\begin{tabular}{|l|l|l|l|l|l|}
\hline Age & $\begin{array}{l}\text { Number of } \\
\text { respondents }\end{array}$ & $\begin{array}{l}\text { Number of } \\
\text { voter }\end{array}$ & Percentage & $\begin{array}{l}\text { Number of } \\
\text { non-casting } \\
\text { voter }\end{array}$ & Percentage \\
\hline $18-24$ & 34 & 26 & $76.8 \%$ & 8 & $23.52 \%$ \\
\hline $25-34$ & 66 & 62 & $93.94 \%$ & 4 & $6 \%$ \\
\hline $35-49$ & 50 & 40 & $80 \%$ & 10 & $20 \%$ \\
\hline $50-59$ & 34 & 24 & $70.59 \%$ & 10 & $29.41 \% \%$ \\
\hline $60-$ above & 16 & 8 & $50 \%$ & 8 & $50 \%$ \\
\hline & Total-200 & Total-160 & & Total-40 & \\
\hline
\end{tabular}

[Source: Field survey]

Table demonstrates that among 34 respondents, 26 (76.80) cast their votes belong to 18-24 age groups, $93.34 \%$ belonging to $25-34$ and $80 \%$ belonging to $35-49$ age groups, $70.59 \%$ belonging to $50-59$ and $50 \%$ belonging to 60 age group. From the above discussion we can say that the respondents of young and middle age groups are both socially and politically more concern, active and enthusiastic about their voting than the old age people.

\section{5: Relationship between Gender and Voting Behavior}

The changing pattern of voting behavior on the basis of gender is remarked in the following table on the basis of field survey.

Table 6: Percentage Distribution of Gender and Voting Behavior

\begin{tabular}{|l|l|l|l|l|l|}
\hline Gender & $\begin{array}{l}\text { Number of } \\
\text { respondents }\end{array}$ & $\begin{array}{l}\text { Number of } \\
\text { voter }\end{array}$ & Percentage & $\begin{array}{l}\text { Number of } \\
\text { non casting } \\
\text { voter }\end{array}$ & Percentage \\
\hline Male & 140 & 124 & $88.57 \%$ & 16 & $11.42 \%$ \\
\hline Female & 60 & 36 & $60 \%$ & 24 & $17.14 \%$ \\
\hline & Total-200 & Total-160 & & Total-40 & \\
\hline
\end{tabular}


[Source: Field survey]

The above table illustrated that among the male respondents $88.58 \%$ cast their votes and $60 \%$ of the female respondents cast their votes. So we can say that the male voters of Annadanagar Union are more concern about their voting than the female voters.

\section{6: Relationship between Education and Voting Behavior}

The table represents how the voting behavior of the local people related with the education level.

Table 7: Percentage Distribution of Education and Voting Behavior

\begin{tabular}{|l|l|l|l|l|l|}
\hline $\begin{array}{l}\text { Level of } \\
\text { Education }\end{array}$ & $\begin{array}{l}\text { Number of } \\
\text { respondents }\end{array}$ & $\begin{array}{l}\text { Number of } \\
\text { voter }\end{array}$ & Percentage & $\begin{array}{l}\text { Number of } \\
\text { non-casting } \\
\text { voter }\end{array}$ & Percentage \\
\hline Illiterate & 40 & 38 & $95 \% \%$ & 2 & $5 \%$ \\
\hline Primary & 40 & 36 & $90 \%$ & 4 & $10 \%$ \\
\hline SSC & 35 & 30 & $85 \%$ & 5 & $14.28 \%$ \\
\hline HSC & 35 & 30 & $85 \%$ & 5 & $14.28 \%$ \\
\hline Graduate & 30 & 18 & $60 \%$ & 12 & $40 \%$ \\
\hline $\begin{array}{l}\text { Post } \\
\text { Graduate }\end{array}$ & 20 & 8 & $40 \%$ & 12 & $60 \%$ \\
\hline & & Total-160 & & Total-40 & \\
\hline
\end{tabular}

[Source: Field survey]

\section{7: Political ideology and voting behavior of the Casting Voters}

Political ideology is an important political determinant of voting behavior. It shapes the decision of the voter. So the question of the level playing field based on the results of the people who believe in political ideology as determinant of voting behavior has been analyzed through this figure:

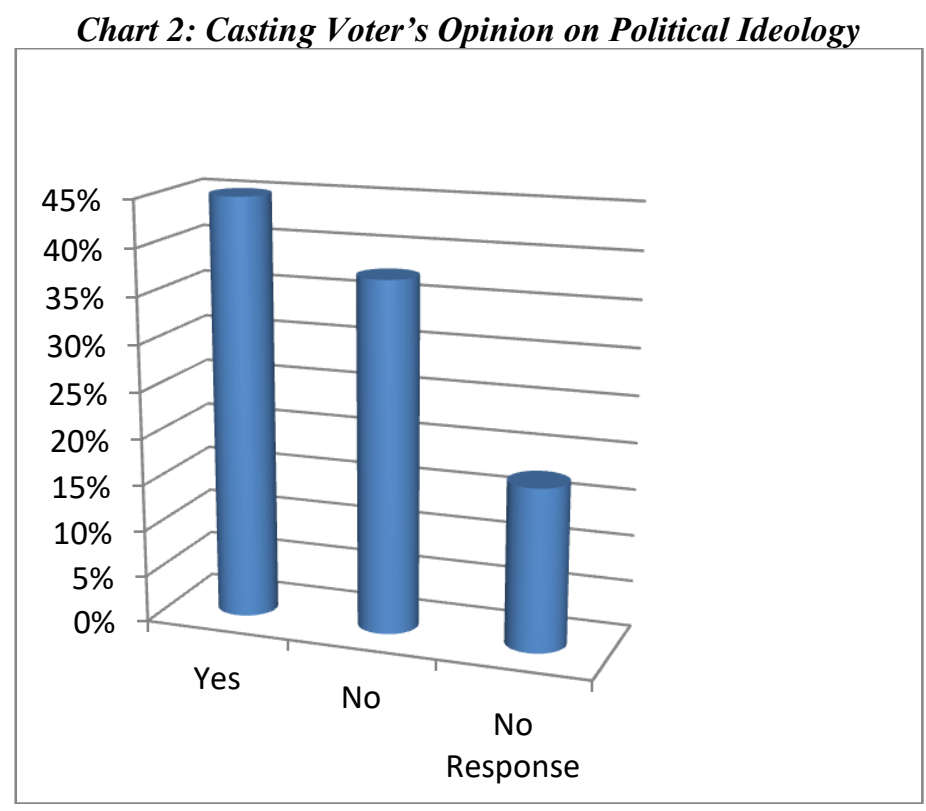

[Source: Field Survey]

It can be seen in the above Chart that, $45 \%$ (72 respondents from 160 whose cast their vote) respondents said that they believe in political ideology, $37.5 \%$ did not believe in political ideology, and $17.5 \%$ ceased themselves from any kind of comment is this matter. 


\section{8: Political Ideology and Voting Behavior of Non-Casting Voters}

This figure illustrated the percentage of believe in political ideology by the non- casting voters.

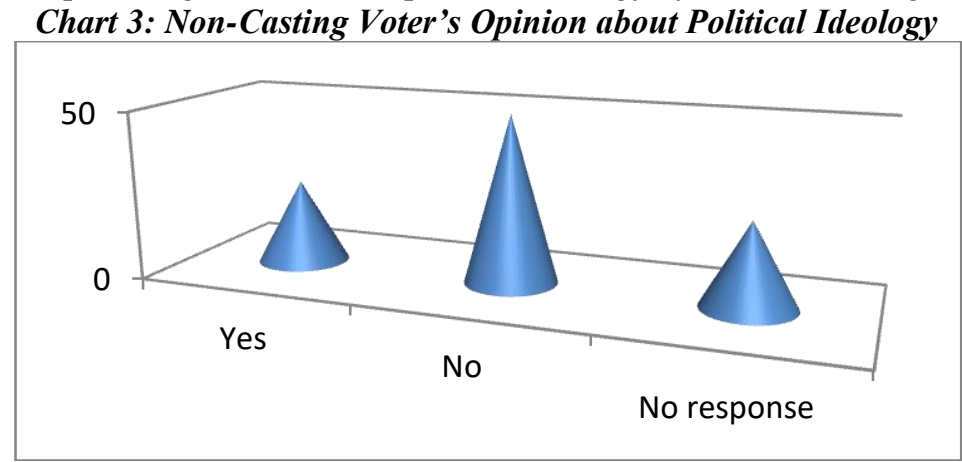

[Source: Field Survey]

It turns out that in chart-3, among 40 (20\% of 200 respondents) non-casting voter $25 \%$ believed in political ideology, and $25 \%$ ceased themselves from any kind of comment in this matter.

\section{9: Party Affiliation and Voting Behavior of Casting Voters}

Political parties are the prerequisite of democracy. Political party creates public opinion about the policy making activities of the government. Further, the political party acted as the watchdog towards government activities, when remain as opposition party. Party affiliation has a close connection with voting behavior. The results of the question who emphasized on party affiliation at the time of voting in local election (UP) among the people of Annadagar Union Parishad is presents here.

\section{Chart: 4: Respondents Opinion on Party Affiliation}

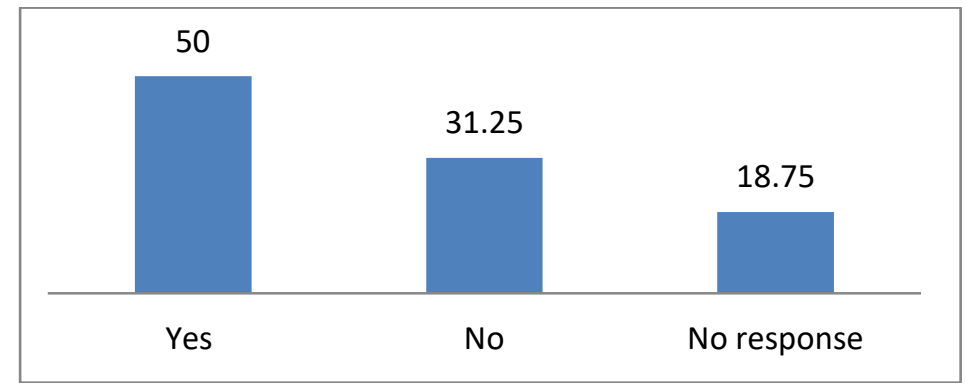

[Source: Field Survey]

From the figure -4 , it can be said that, among the total number of the casting voter $50 \%$ believed in party affiliation. They said that the party affiliation greatly influenced their decision at the time of voting. $31.25 \%$ voter said that they did not take the party affiliation as the factor of voting in the local election. And $18.75 \%$ respondents said that they didn't have any opinion about the party affiliation.

6.10: Number of Activist of political Party (Among 80 people who believe in party affiliation) Chart 5: Percentage of the Activist of political Party 




[Source: Field Survey]

Chart 5: $44 \%$ of 80 respondents remarked that they are not activist of political party, $37 \%$ said that they are the activist of political party and 19\% respondents said that they did not have any opinion in this regard. The data of this table explained that majority percent voter is no longer an activist of any political party.

\subsection{1: Get Benefited from Political Party (Among 160 people who are casting their vote)}

- Get benefitted from political party for which candidate people cast their vote is a remarkable issue of party affiliation. Most of the time the people cast their vote on the basis of benefits which comes from political party. So the question about get benefitted from political party on the basis of the results obtained from the field level by any organization has to be analyzed by the given images.

\section{Chart 6: Respondents Opinion about Get Benefited from Political Party}

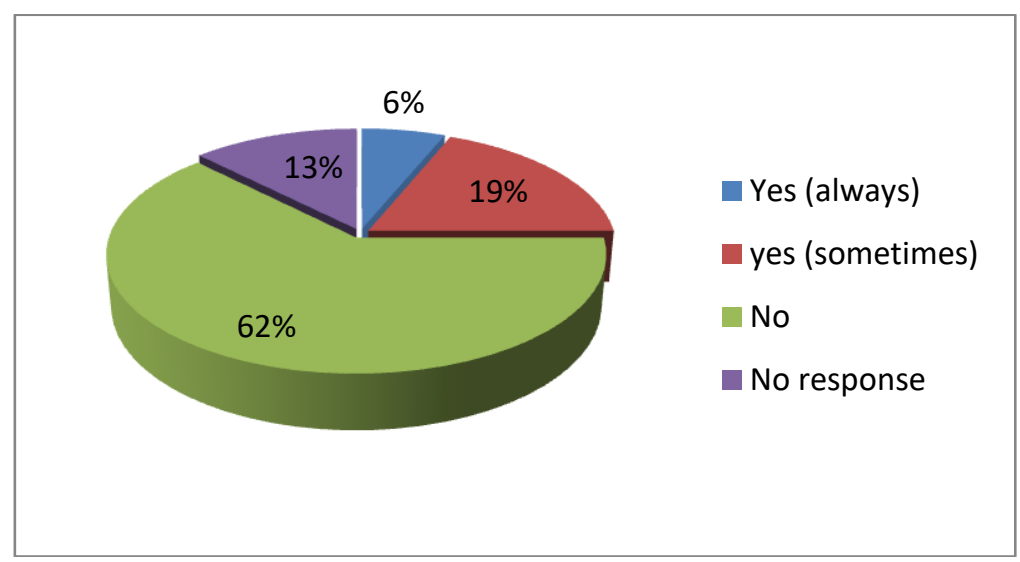

[Source: Field Survey]

Figure-5.8 illustrated that, among the respondents 160 whose casting their vote $62.5 \%$ (100) of them said that they had not get any benefit from the political party. $18.75 \%$ (30) get sometimes, $6.25 \%$ (10) said that they get always and $12.5 \%(20)$ told that they have no opinion.

\subsection{2: Type of Benefits}

The result of the question about types of benefit has been showed in the following figure.

Chart 7: Respondents Opinion about Various Types Benefits 


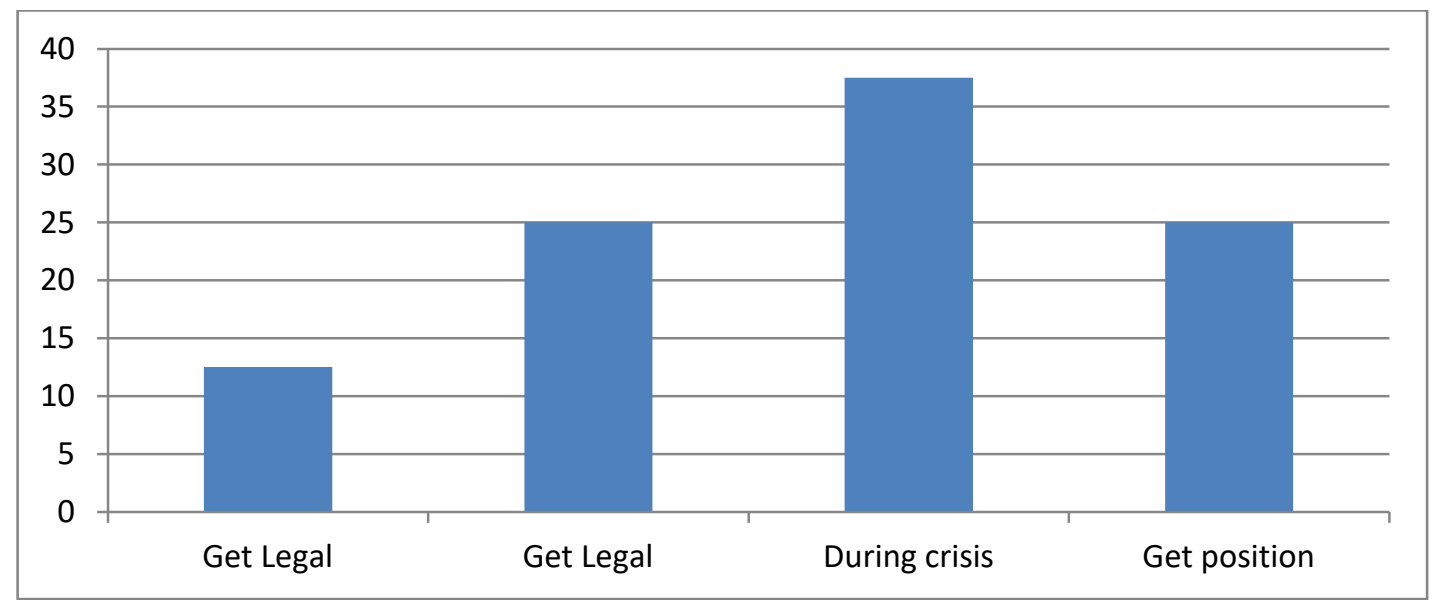

[Source: Field Survey]

Figure -7 demonstrates that, among 40 whose get benefitted (always \& sometimes), $12.5 \%$ answered that they get legal helps, $25 \%$ get cash, $37.5 \%$ get helps during crisis moments, $25 \%$ get position in party committee. According to the figure majority percent get benefitted during the crisis moments which inspired them to vote.

\subsection{3: Belief in Party Affiliation by Non-Casting Voters}

How the party affiliation affect the voting behavior of the non- casting voter the results of this question analyzed here through the given figure on the basis of survey data.

\section{Chart 8: Percentage of Non-Casting Voters Belief in Party Affiliation}

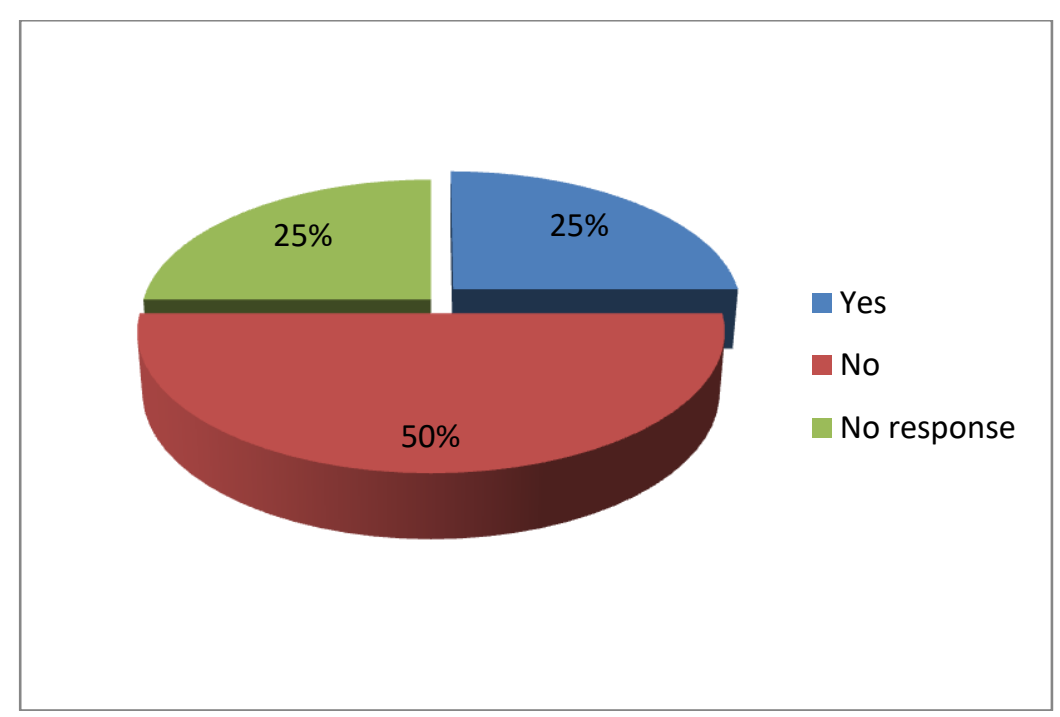

Chart- 8 depicts that, among the non-casting voter 40 of the total respondents $50 \%$ told that the party affiliation did not encouraged them to vote, $25 \%$ told that they believed in party affiliation and $25 \%$ ceased themselves from any kind of comment about party affiliation.

\subsection{4: Get Benefited from Political Party}

Among the non-casting voter who get / not get benefitted from political party the figure in bellow analyzed the results of this question on the basis of data from survey report. 


\section{Chart 9: Respondents Opinion about Get Benefited from Political Party}

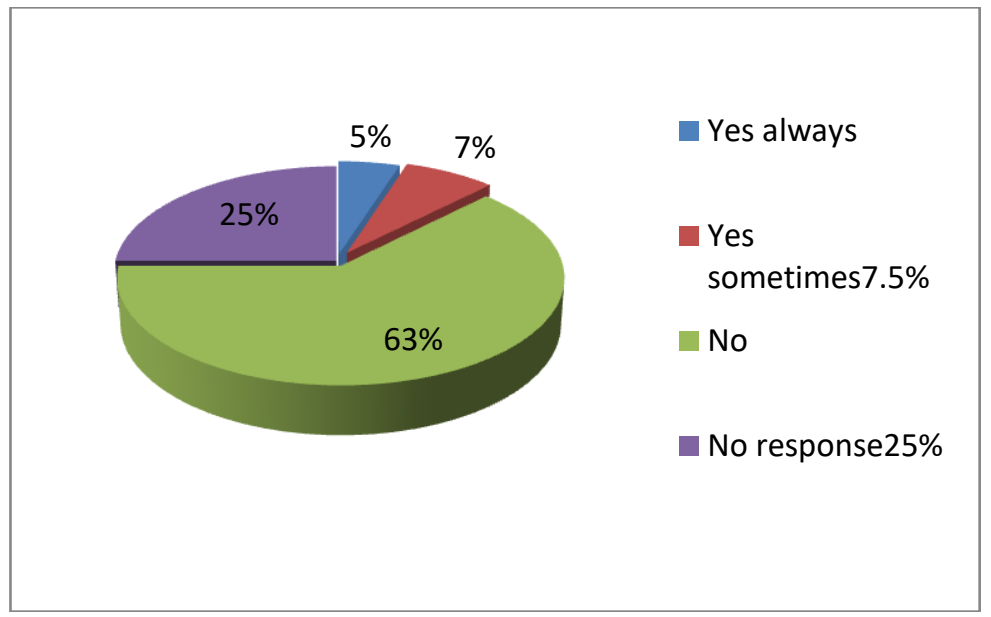

Chart- 9 analyzed that, among the non-casting voter, $62.5 \%$ respondents answered that they had not get any types of benefit from the political party for which candidates they cast their vote, $7.5 \%$ get sometimes , only $5 \%$ get always and $25 \%$ told that they had no opinion about this issue as per table no.5.17. The figure illustrated that, majority percent had not get benefitted which discouraged them to vote heavily.

\subsection{5: Types of Benefits}

The results of the question about types of benefits get by non-casting voter are presented through the given table in bellow on the basis of field data.

\section{Chart 10: Respondents Opinion about Various Types Benefits}

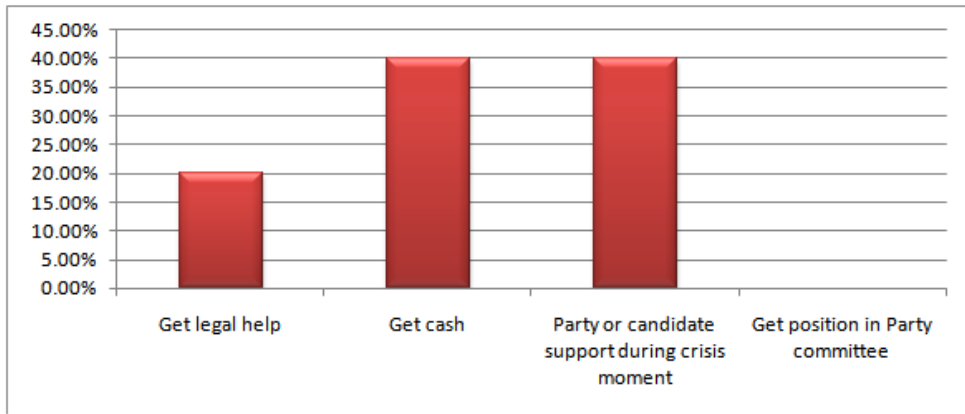

According to the table- 10 , among the non-casting voter whose told that they get benefitted $20 \%$ of them get legal help, $40 \%$ get cash, $40 \%$ get support during crisis moments and no voter can get position in part committee.

6.16: Candidates Qualification and Voting Behavior of Casting Voters

Candidate's personal image or qualification is another important determinant for shaping voting behavior.

\section{Chart 11: Opinion of Casting Voters about Candidates Qualification}




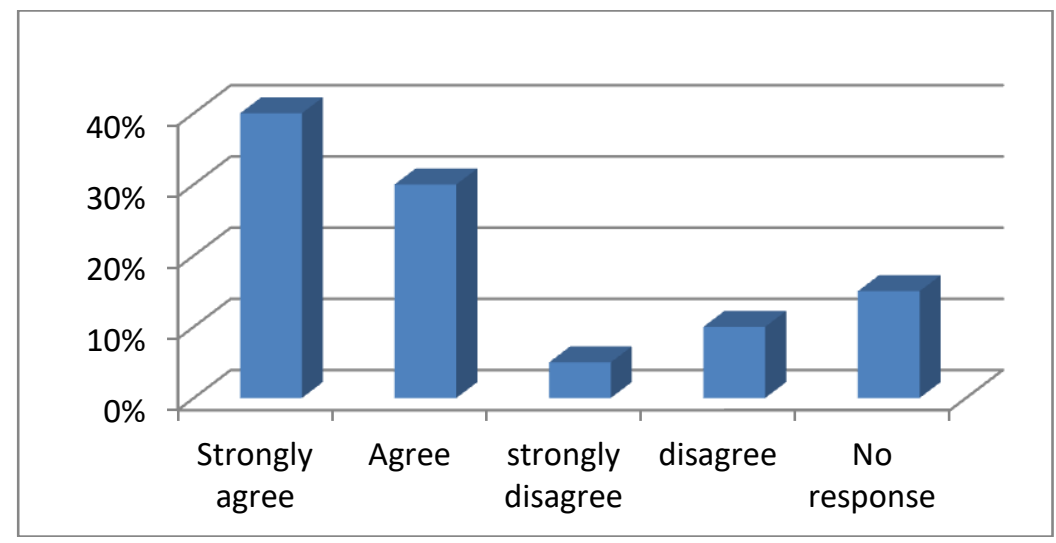

Chart-11 illustrates that, among the casting voter, $40 \%$ respondents told that they strongly believed on candidate's qualification as the factor which shapes voting behavior, 30\% generally agree, $5 \%$ strongly disagree about this issue and $15 \%$ respondents ceased themselves from any kind of comment.

\section{FINDINGS}

The first objective of the research isto investigate the determinants that contribute to the voter's decision either to cast votes or not to cast votes. In chapter six named findings I have included the determinants which I have get from the field survey. So, first estimation of the research is proved from the above discussion and from the information and data from six. Second and third objectives of the research were to compare the voting behavior of voters who cast their vote and non-casting voters and to find out and analyze the influence of socio-demographic determinants such as ethnicity, gender, religion education age etc. and politicopsychological factors such as perception, security situation, local factors, party affiliation, ideological affiliation of candidates and voters, etc. in determining voters choices such as either to voter or whom to vote and whom not to. In the chapter theoretical framework I have showed the general comparison between casting voters and non-casting voters. And in chapter six I have explained the comparison between casting voters and non-casting voters of the people of Annadanagar Union through frequency table and chart which mostly helped to clear the comparing relationship. Here the impact of socio- politico and economic determinants on the voting behavior of the local people. The study reveals that voting turnout by age, gender, and education was different. The young and middle aged people are more encouraged to voting than the old people. Female voters are less encouraged to vote than male. And illiterate voters are interested to vote more than educated because the illiterate voters voting mainly depends on the level of get benefitted, they don't think about the electoral process, candidates qualification etc. On the contrast majority percentage educated voter think about these matter. So we can conclude that second objective of the research is proved.

\section{CONCLUSION AND RECOMMENDATIONS}

Elections have always been a feature of democratic process. Democratic institutions thrive on the exercise of choice at regular intervals by the electorate. Elections act as a safeguard of democratic freedom and, among other things, make for the rotation of rulers and create the potential for leadership. Local elections have established a bridge between electorate and candidature. As a result the importance of local elections is not less than national elections. The study reveals that the voting behavior of local people shaped by some determinants. They became encouraged to vote and sometimes ceased them from vote for some remarkable causes.

\section{1: Recommendations}

On the basis of some problems which remarked in the research I have tried to recommend in some important point and hope that these will be bring a positive image.

I. The local people become fed up for the existing corruption in election. They don't get enough services for ineffectiveness of the body of local government which is harmful for democracy. So,the government should try to take necessary measures to reduce these problems to create interest to non- casting voters to vote.

II. The number of women in voting is more less than male for lack of women education, lack of consciousness and some women complained that they can't cast their vote according to their own desire. Their husband, father interferes on their opinion. So the Government should take steps to increase the rate of education for both women and men. 
III. The media is an important tool to represent and reflect the real picture of every aspect of life especially politics. The media should play a positive role in politics and create awareness among the local people regarding hot and current political issues that are prevailed on politics in the country.

IV. Awareness should be creates among the people about the importance of local election and the value of their participation in voting. Various type of violence during election period is another cause of note voting. As a result the necessary steps should be taken to stop the election related violence.

\section{BIBLIOGRAPHY}

[1] Abbas, (2014),' Social Factors Hindering Political Participation in Pakistan: A Review Article,' Mediterranean Journal of Social Sciences, MCSER Publishing, Rome-Italy, Vol -5 No 23, November.

[2] Ahmed, Nizam, (2000), 'Politician and Bureaucrats in Local Government in Bangladesh: Social Background and Role of Orientation', The Journal of Local Government, Vol. 29, No. 1, January-June, 2000 .

[3] Akhter, Muhammad Yeahia,(2001) ',Electoral Corruption in Bangladesh', Hampshire, Ashgate Publishing Ltd.

[4] Alam,A.Z.MSamsul, (1986), 'Democracy and Election,' Dhaka, Bangladesh Co-operative Book Society Ltd.

[5] Blais. A.G. Elizabeth and N.Neil.(2004). Where Does Turnout Decline Come From? European Journal of Political Research.43:221-23.

[6] Bratton, Michael (2013) 'Voting And Democratic Citizenship in Africa'. University Press Ltd.

[7] Cohen.K.(2003).Journal of Personality and Social Phychology.85:pp:808-22.

[8] Diener, Ed (January 2000). "Subjective well-being: the science of happiness and a proposal for a national index". American Psychologist. American Psychological Association via PsycNET. 55 (1): 34-43. doi:10.1037/0003-066x.55.1.3.

[9] Goldman, Sheldon (June 1966). "Voting behavior on the United States Courts of Appeals, 1961-1964". The American Political Science Review. Cambridge Journals. 60 (2): 374-383. doi:10.2307/1953364. JSTOR 1953364.

[10] Harder, Joshua and Krosnick, Jon, A, (2008), 'Why Do People Vote? A Psychological Analysis of the Causes of Voter Turnout', Journal of Social Issues.Vol-64.No.3

[11] Harrop, M and and. Miller, W. L, 'Elections and Voters: A Comparative Perspective, 1987).'

[12] Harun, Shamsul Huda (1986) 'Bangladesh Voting Behaviour: A Psychological Study1973', Dhaka, The University of Dhaka

[13] Hye, Hasnat, Abdul, (1974)' Village Studies in Bangladesh,' Comilla, Bangladesh Academy for Rural Development,'

[14] Islam, S.M, Jajirul,Hasan,(1999)',Voting Behavior of the Village People in Union Parishad Election: A case study on Gunaigach Union Parishad', S.M.S.Thesis, Savar, Department of Government and Politics, Jahangirnagar University.

[15] Khan, M. Salimullah and Ahmhed, KaziSaleh,(1984), 'Belief System, Party Preference \& Voting Behavior: A Case Study of Four Villages, The Journal of Satistics Department, Jahangirnagar University, Vol. 4.

[16] Lednum. G.(2006). Asses the Importance of Social Class to Voting Behaviour in the UK.2006.

[17] Lipset, S.M (1960) 'Political Man', New Delhi: Arnold- Heinemann India

[18] Mahmud, Dr, Babak., Shohel,Malik, Mahmud., Mushtaq, Shahzad, Kaver., Rizvi, Sayyed, Rahman, A.F.M, AtaurandSarwar, zayeema,(2015),'Explaining Voter Participation: Evidence From Bangladesh', International Reviews of Business Research Papers, Vol-11, No.2, September.

[19] Milbrath, Lester W and Goel, M. L (1977) 'Political Participation: How and Why Do People Get Involved in Politics? New York: University Press America.

[20] MJ, McGregor, Robert, (2012) "When voters decide: Causes, correlates and effects of time-of-voting decision". Graduate program in political science

[21] Paskert, Michael,(2014),'Effects on Voting Behavior and Voter Turnout,' Senior Honors Projects. Paper 44

[22] Rahman, A. H. M. Aminur,(1990),' Politics of Rural Local Self Government in Bangladesh', Dhaka, DhakaUniversity.

[23] Recent turnout in UK General Elections Politics - Voting Behaviour

[24] Shawar, Durre and Asim, Muhammad,(2012).' Voting Behavior of People Towards Different Political Parties in District Faisalabad' 
[25] Siddiqui, Kamal, (2000), 'Local Government in Bangladesh',(Revised Third edition). Dhaka: University Press Limited. 5. Jahan, Rounaq,' (1980), Bangladesh Politics: Problems and Issues', Dhaka, University Press Limited, 1980.

[26] The Constitution of the People's Republic of Bangladesh.'

[27] Verba, Sidney, Nie, Norman. H and Kim, Jae-On (1978) 'Participation and Political Equality: A Seven Nation Comparison, London: Cambridge University Press.

[28] Wahab, M. Abdul, (1986), 'Local Level Political Affiliation in Bangladesh', The Journal of Political Science Association. 